Barbara Sordyl-Lipnicka

(D) https://orcid.org/oooo-0002-3893-1359

Uniwersytet Papieski Jana Pawła II w Krakowie

\title{
Polska rodzina w obliczu emigracji zarobkowej do Holandii. Kwestie adaptacyjne i tożsamościowe
}

https://doi.org/10.15633/9788374389839.14

Emigracja zarobkowa rodzin to zjawisko znane na całym świecie. Mobilność społeczna rodzin czy pojedynczych osób wciąż determinowana pozostaje chęcią zmiany miejsca zamieszkania oraz poprawą warunków materialnych. Jak zaznacza Danuta Olszewska, emigracja to „dobrowolne opuszczenie kraju rodzimego, forma migracji ludzi. Zjawisko związane z poczynaniami politycznymi lub ekonomicznymi. Emigracja może być korzystna dla kraju przyjmującego lub sprzeczna z jego narodowym interesem. Emigranci organizują się na obczyźnie, powołując zalążki instytucji politycznych, mogą stosować lobby na rzecz własnych interesów”.

Wydaje się, że aktywność zarobkowa rodzin poza granicami ojczyzny stanowi również ważny element historii narodu polskiego. Silny wzrost emigracji zarobkowej, obserwowany szczególnie po 2004 roku, kiedy Polska stała się jednym z państw członkowskich Unii Europejskiej, podkreślił wieloletnią tradycję ruchu emigracyjnego wśród wielu Polaków.

Współczesna emigracja zarówno dla dorosłych, jak i dzieci wiąże się z radykalną zmianą dotychczasowego środowiska życia. Obejmuje swoim zakresem zmianę warunków społecznych, kulturowych oraz ekonomicznych. Decyzje o wyjeździe zarobkowym dorosłych najsilniej wpływają na sposób funkcjonowania dzieci. W ich przypadku zmiana miejsca za-

1 D. Olszewska, Migracje Polaków po przystapieniu do Unii Europejskiej. Szansa dla polskich obywateli czy zagrożenie gospodarcze dla Polski?, w: Polska w Unii Europejskiej, red. J Fischer, Warszawa 2009, s. 517. 
mieszkania i kontakt z osobami odmiennej kultury mogą powodować szereg problemów w ich codziennym funkcjonowaniu (szczególnie w obszarze adaptacyjnym). Dziecięca percepcja emigracji zarobkowej nie zawsze musi wiązać się z poczuciem zabezpieczenia materialnego czy godniejszymi warunkami życia, lecz może być identyfikowana jako sytuacja trudna dla samego dziecka. Niniejszy artykuł stanowi próbę ukazania specyfiki funkcjonowania polskich rodzin przebywających na emigracji w Holandii z perspektywy dziecka jako osoby bezpośrednio doświadczającej zmiany środowiska życia.

\section{Exodus Polaków do Holandii - rys historyczny}

W historia polskiego ruchu emigracyjnego do Holandii można wyróżnić kilka charakterystycznych etapów (okresów), związanych z podejmowaniem przez Polaków decyzji o opuszczeniu ojczyzny.

Polacy na masową skalę docierali do Holandii już w końcu XIX wieku, kierując się ścieżkami wyznaczanymi przez procesy industrializacji oraz rozwój sektora górniczego (na obszarze Limburgii znajdowali zatrudnienie w kopalniach węgla kamiennego). Część z nich pozostawała na stałe na emigracji, niektórzy wracali do ojczyzny. W rezultacie jeszcze przed II wojną światową w Holandii utworzyły się zręby późniejszej Polonii. Kolejnym ważnym etapem w historii polskiej emigracji do Królestwa Niderlandów okazało się osiedlenie się w Bredzie żołnierzy I dywizji pancernej gen. S. Maczka i I brygady spadochronowej gen. Sosabowskiego, którzy po II wojnie światowej nie zdecydowali się na powrót do komunistycznej ojczyzny. Następny okres emigracji przypadł na lata powojenne (szczególnie lata 6o., 70. i 80.) gdy wraz z drastycznie pogarszającymi się nastrojami w kraju, głównie prześladowaniami, istotnie wzrastała skala wyjazdów z Polski oraz migracje z okresu pierwszej fazy transformacji².

W latach 90. xx wieku oraz w pierwszej dekadzie xxı wieku zmieniają się przyczyny, dla których Polacy emigrują do Holandii. Większość z nich pragnie poprawić warunki bytowe, uzyskać wyższe kwalifikacje zawodo-

2 S. Toruńczyk-Ruiz, Being together or apart? Social networks and notions of belonging among recent Polish migrants in the Netherlands, „CMR Working Papers” (2008) nr 40/98. 
we, sprawnie posługiwać się językiem angielskim. Holandia w tym czasie promuje politykę imigracyjną i otwiera się na nowo przybyłych Polaków. Akcesja Polski do Unii Europejskiej w 2004 roku stanowiła niezwykle ważny etap i zarazem bodziec do podjęcia przez dużą grupę Polaków decyzji o emigracji do Holandii. Celem przybyłych po 2004 roku Polaków do Holandii było przede wszystkim podniesienie kwalifikacji zawodowych, polepszenie warunków socjalno-bytowych, osiąganie wyższego wynagrodzenia, możliwości lepszego rozwoju, skorzystanie $\mathrm{z}$ atarkcyjnej oferty edukacyjnej. Ponadto Polacy chętnie wybierali Holandię jako kraj docelowej emigracji, gdyż prezentował on podobne warunki geograficzne i przyrodnicze do Polski oraz wysokie wskaźniki ekonomiczne i gospodarcze wśród europejskich państw ${ }^{3}$. Z danych ambasady Rzeczypospolitej Polskiej w Hadze wynika, że około 87 ooo. Polaków mieszka tam na stałe, a ponad 200 ooo. przebywa czasowo. Od 2010 roku Holandia uznaje Polaków za mniejszość etniczną, która jednocześnie stanowi największą grupę migrantów z Europy Środkowo-Wschodniej, a także spośród wszystkich członków Unii Europejskiej ${ }^{4}$.

$\mathrm{Z}$ raportu Instytutu Spraw Publicznych (zleconego przez Ministerstwo Spraw Zagranicznych) na temat wizerunku Polski i Polaków w Holandii wynika, że Holendrzy uważają Polaków za bardzo pracowite osoby (73\% badanych), które wykonują głównie prace niewymagające kwalifikacji (prawie 6o\%), a zdecydowana większość z nich przebywa w Niderlandach tylko czasowo, celem uzyskania większych środków materialnych. Ponadto Polacy budują wizerunek ojczyzny w państwie przyjmującym swoją postawą, zachowaniem oraz tym, w jaki sposób wypowiadają się o Polsce ${ }^{5}$.

Różnica między etapami emigracji Polaków do Holandii związana jest z procesem adaptacyjnym, integracyjnym i asymilacyjnym poszczególnych imigrantów z Polski. Można przypuszczać, że obecne migracje zarobkowe wpływają na kształtowanie się teraźniejszości i przyszłości wielu

3 J. Leska-Ślęzak, J. Ślęzak, Młoda polska emigracja do Holandii, „Cywilizacja i Polityka” (2016) nr 14, s. 176.

4 J. Leska-Ślęzak, Sytuacja mniejszości narodowych i etnicznych w Holandii, w: Mniejszości narodowe i etniczne w Polsce i Europie. Aspektypolityczne i spoteczne, red. A. Sakson, Toruń 2014, s. 21.

5 Raport Jacka Kucharczyka przeprowadzony na zlecenie Ministerstwa Spraw Zagranicznych, (podbrano dnia 28.10.2019. $\mathrm{z}$ http://www.isp.org.pl/uploads/filemanager/PrezentacjaWarszawa191220123). 
polskich rodzin. Wobec pojawiających się nadal trudności na rodzimym rynku pracy wyjazdy zagraniczne stają się dla wielu Polaków szansą na polepszenie warunków życia ich rodzin. W 2019 roku, według danych Głównego Urzędu Statystycznego ${ }^{6}$, poza granicami Polski przebywało czasowo około 2415 ooo jej mieszkańców, w tym około 2134 ooo osób przebywało w Europie, zwłaszcza w krajach członkowskich Unii Europejskiej. Najwięcej polskich obywateli emigrowało do Niemiec (704 000), Wielkiej Brytanii (678 ooo) oraz Holandii (125 0oo).

\section{Emigracja zarobkowa a rodzina}

Emigracja zarobkowa dla wielu polskich rodzin odbywa się w sytuacji przemian społecznych związanych z procesem konwergencji. Liczne grupy polskich rodzin próbują zbliżyć warunki życia do tych, które funkcjonują w rozwiniętych społeczeństwach zachodnich, by ty samym móc zabezpieczyć własne potrzeby życiowe. Obecna emigracja zarobkowa jest jednak łatwiejsza w realizacji, głównie z uwagi na coraz bardziej postępujący rozwój sieci transporotowo-komunikacyjnych, ułatwiający nie tyle zmianę miejsca pobytu i przemieszczanie się, ale przede wszystkim pozostawanie $\mathrm{w}$ dobrym kontakcie z bliskimi, którzy nie biorą udziału w emigracji. W efekcie współczesna emigracja sprzyja podwójnej przynależności emigrantów do kraju wysyłającego i przyjmującego, przybiera formę podwójnego obywatelstwa i może być rozpatrywana w szerszych kategoriach transnarodowości?

Specyfika emigracji zarobkowej polskich rodzin ujawnia również istnienie co najmniej dwóch grup emigrantów, charakteryzujących się określonym stylem życia. Pierwszą grupę stanowią osoby, które emigrują wspólnie z całą rodziną poza granice kraju ojczystego. Najczęściej podejmują oni decyzję o stałym osiedleniu się w kraju docelowej emigracji, przejawiają mniejsze lub większe problemy związane ze stresem akulturyzacyjnym członków rodzin. Z kolei drugą grupą są te osoby, które samodzielnie lub

6 Informacja o rozmiarach i kierunkach czasowej emigracji z Polski w latach 2004-2019. Informacja sygnalna w formacie PDF (stat.gov.pl) (10.04.2020).

7 B. Cieślińska, Emigracje bliskie i dalekie Studium wspótczesnych emigracji zarobkowych na przykładzie województwa podlaskiego, Białystok 2012, s. 15 
z małżonkiem emigrują i pozostawiają członków rodziny w Polsce (najczęściej dzieci). Taka sytuacja doprowadza do redefiniowania tożsamości dorosłych członków rodziny oraz do kreowania się tożsamości tych najmłodszych ${ }^{8} \mathrm{w}$ perspektywie jednostkowego i społecznego funkcjonowania. W wyniku emigracji zarobkowej dochodzi przede wszystkim do zmiany otoczenia społecznego oraz nabycia przez jednostkę nowej pozycji w społeczeństwie przyjmującym ${ }^{9}$. Szereg konsekwencji emigracji zarobkowej dla funkcjonowania rodzin rozłączonych został ukazany w licznych badaniach naukowych ${ }^{10}$.

W rodzinie przebywającej na emigracji życie pojedynczych osób ulega ciągłej reorganizacji. Dorośli mogą nieustannie zmagać się z problemami zawodowymi, często zmianą w zakresie wykonywanych profesji, wydłużeniem czasu pracy, niezadowoleniem z poziomu zabezpieczenia finansowego, które jest rezultatem ich czynności zawodowych. Dzieci zmuszone są z kolei do odnalezienia własnej przestrzeni w grupie rówieśniczej, szkole, środowisku zamieszkania. Nowy świat bywa dla nich niezawsze zrozumiały, a czasem wręcz przerażający. Pobyt na emigracji może być trwale bądź okresowo sytuacją trudną, której następstwa dla funkcjonowania człowieka mogą być następujące:

- zaburzenia fizjologiczne prowadzące niejednokrotnie do nastawienia lękowego i rezygnacyjnego;

- określone urazy psychiczne, różniące się strukturą, intensywnością, okresem oddziaływania;

- korzystne zachowania związane z założeniem, że sytuacje trudne mogą prowadzić również do zmian pozytywnych (teoria kryzysu Geralda Caplana, teoria dezintegracji pozytywnej Kazimierza Dąbrowskiego) ${ }^{11}$.

8 M. Mead, Kultura i tożsamość. Studium dystansu międzypokoleniowego, Warszawa 200o, s. 29.

9 B. Cieślinska, Motywy emigracji niezamężnych kobiet na przykładzie Podlasia, w: Migracje kobiet. Perspektywa wielowymiarowa, red. K. Slany, Kraków 2008, s. 266.

10 D. Gizicka, J. Gorbaniuk, M. Szyszka, Rodzina w sytuacji roztąki migracyjnej, Lublin 2010; W. Danielewicz, Rodzina ponad granicami. Transnarodowe doświadczenia wspólnoty rodzinnej, Białystok 2010; I. Szczygielska, Migracje zarobkowe kobiet i ich wptyw na funkcjonowanie rodzin, Warszawa 2013.

11 A. Jacyniak, Z. Płużek, Świat ludzkich kryzysów, Kraków 1996. 
W zależności od przyjętych środków zaradczych emigranci mogą w różny sposób radzić sobie z sytuacjami o charakterze trudnym bądź nawet kryzysowym podczas pobytu w kraju docelowej emigracji. Kalervo Oberga $^{12}$ zakłada, że pobyt na emigracji związany jest głównie $\mathrm{z}$ adaptacją kulturową, która zazwyczaj przebiega w następujących po sobie fazach:

- faza miesiąca miodowego - oznaczająca fascynację nową kulturą;

- faza szoku kulturowego - podczas której odczuwalna staje się bariera językowa i w związku z tym wrogie nastawienie do kultury, z którą emigrant się spotyka;

- faza ożywienia - w zakresie której emigrant uczy się nowego języka i zdecydowanie efektywniej radzi sobie w różnych sytuacjach życiowych;

- faza dopasowania - związana z akceptacją innych osób, nowych norm kulturowych, adaptacją i otwartością na nowe środowisko.

Każda $\mathrm{z}$ wymienionych faz adaptacji kulturowej generuje określone stany emocjonalne pojawiające się u poszczególnych osób (dzieci i dorosłych). Bywa jednak, że czynniki postemigracyjne, takie jak: utrata bliskiego otoczenia społecznego, izolacja społeczna, utrata dotychczasowych ról społecznych oraz zawodowych w zdecydowanie większym stopniu przyczyniają się do pourazowych reakcji stresowych oraz cierpienia emocjonalnego i fizycznego emigranta ${ }^{13}$.

Każda zatem osoba emigrująca (dorosły lub dziecko) w indywidualny sposób postrzega emigrację zarobkową i jej wpływ na poziom funkcjonowania rodzinny. Często ocena własnych doświadczeń życiowych związana jest $\mathrm{z}$ aktualnym obrazem stanu psychicznego osoby doświadczającej emigracji.

Najnowsze badania wskazują, że zagadnienie emigracji zarobkowej rodzin wciąż pozostaje interesującym obszarem badawczym, szczególnie w zakresie analizy czynników determinujących poziom funkcjonowania polskich rodzin w perspektywie zagranicznej mobilności zawodowej. Badacze podkreślają, że sposób reagowania rodziny na sytuację emigracji jest zdeterminowany wieloma czynnikami. Przede wszystkim ważna jest kon-

12 K. Oberg, Culture Shock. Adjustment to New Cultural Environments, „Practical Anthropology" (1960) no. 7 (pobrano dnia 26.03.2014 z http://agemethnomedizin.de/download/ cu29_2-3_2006_S_142-146_Repr_Oberg.pdf). 
dycja psychospołeczna rodziny i poziom jej funkcjonowania przed podjęciem decyzji o emigracji. Ważne są również zasoby rodziny pozwalające przystosować się do nowej sytuacji, faza życia małżeńskiego i rodzinnego, w której wystąpiła emigracja, okres emigracji, percepcja społeczna emigrantów oraz postawy i zachowania społeczności przyjmującej ${ }^{14}$.

Emigracja zarobkowa, w której uczestniczą całe rodziny, może posiadać cechy sytuacji trudnej, jednak nie zawsze tak musi być. Wiele polskich rodzin przebywających na emigracji przyjmuje przemyślane strategie wychowawcze i edukacyjne wobec dzieci funkcjonujących w nowej, bardzo często wielokulturowej rzeczywistości ${ }^{15}$. Młodsze dzieci - z uwagi na to, że łatwiej niż dzieci starsze adaptują się do nowej szkoły i szybciej uczą się języka - zdecydowanie częściej są zachęcane przez rodziców do poznawania nowej rzeczyczywistości ${ }^{16}$. Z kolei badania Dariusza i Aleksandry Galasińskich ${ }^{17}$ ukazują, że kontakt emigrantów z różnorodnością kulturową innych osób może stymulować ich społeczną tożsamość.

\section{Metodologia badań własnych}

Prezentowane $\mathrm{w}$ tekście badania stanowią wybrany fragment projektu badawczego dotyczącego problematyki wychowawczego i społecznego funkcjonowania polskich dzieci doświadczających emigracji zarobkowej rodziców oraz całej rodziny ${ }^{18}$. W celu analizy specyfiki funkcjonowania polskich rodzin emigrujących do Holandii (z perspektywy dziecka) podjęto próbę odpowiedzi na następujące pytania badawcze:

1. Jak w ocenie dziecka funkcjonuje rodzina, która emigruje zarobkowo do Holandii pod względem:

14 T. Biernat, P. Krakowiak, T. Leszniewski, Emigracja zarobkowa jako sytuacja trudna ( $w$ świetle aktualnych badań nad polskimi migrantami $w$ Wielkiej Brytanii), „Pedagogika Społeczna" (2019) nr 1 (71), s. 191.

15 A. White, Polish Families and Migration Since EU Accession, Bristol 2017.

16 L. Ryan, R. Sales, Family Migration: The Role of Children and Education in Family Decision-Making Strategies of Polish Migrants in London, „International Migration” 2 (2013), s. 90-103, https://doi.org/10.1111/j.1468-2435.2010.00652.x.

17 D. Galasiński, A. Galasińska, Lost in Communism, Lost in Migration: Narratives of the Post1989 Polish Migrant Experience, „Journal of Multicultural Discourses” (2007) no. 1, s. 47-62.

18 W prezentowanym artykule omówiono głównie obszar funkcjonowania rodzin przebywających na emigracji w Holandii. 
- spójności (więzi emocjonalne między członkami rodziny),

- adaptacyjności (zdolność do zmian w strukturze, układzie ról, zasadach)

- wzajemnego zrozumienia w sytuacji emigracji zarobkowej?

2. Czy i w jakim stopniu w rodzinie pojawiają się (patogenne) role rodzinne w sytuacji emigracji zarobkowej?

3. Czy i w jakim stopniu w rodzinie emigrującej zarobkowo występują trudności rozwojowe oraz przejawy dezintegracji?

4. Jakie jest ogólne poczucie funkcjonalności rodziny doświadczającej emigracji zarobkowej?

Rozwiązanie problemu badawczego wymagało wyboru odpowiedniej metody badań, w tym przypadku metody sondażu diagnostycznego. W badaniach zastosowano następujące techniki badawcze (wywiad i skale ocen) oraz narzędzia badawcze, tj. autorski „Kwestionariusz wywiadu z Dzieckiem” i Inwentarz „Profil Rodziny” w opracowaniu Zbigniewa B. Gasia ${ }^{19}$. Inwentarz tworzy sześć skal, z których trzy dotyczą pozytywnych wymiarów funkcjonowania rodziny (m.in. skala spójności, adaptacyjności i wzajemnego zrozumienia), a kolejne trzy odnoszą się do negatywnych przejawów funkcjonowania rodziny (skala patogenne role rodzinne, trudności rozwojowe, dezintegracja rodzinna).

Badana próba liczyła 120 uczniów (62 dziewczynki, 58 chłopców) pochodzenia polskiego. Respondenci uczęszczali na zajęcia do Szkolnego Punktu Konsultacyjnego przy Ambasadzie Rzeczpospolitej Polskiej w Hadze oraz na spotkania przy polskiej parafii św. Maksymiliana Marii Kolbe w Bredzie.

Analiza statystyczna grupy respondentów nie wskazała na znaczne różnice liczebności obu płci w badanej próbie [test proporcji $(Z=1,12 ; p>0,1)$ ]. Badania wskazały ponadto, że najliczniej reprezentowane były dzieci w wieku 15 lat (30\%), a najmniej liczna była grupa 13-latków (16,7\%). Za pomocą jednoczynnikowej analizy wariancji ANOva stwierdzono istotne zróżnicowanie wieku badanych dzieci $(\mathrm{F}=32,648 ; \mathrm{p}<0,001)$. W rodzinach tych wychowywały się istotnie starsze dzieci niż młodsze.

19 Z. Gaś, Badanie zapotrzebowania na profilaktykęw szkole. Poradnik dla szkolnych liderów profilaktyki, Lublin 2004. 


\section{Analiza wyników badań własnych i dyskusja}

Analiza średnich surowych wyników uzyskanych w badaniach Inwentarzem „Profil Rodziny” Zbigniewa Gasia w grupie respondentów przebywających na emigracji w Holandii przedstawia poniższa tabela.

Tabela 1. Średnie i odchylenia standardowe dla poszczególnych skal Inwentarza „Profil Rodziny”

\begin{tabular}{|l|c|c|}
\hline \multirow{2}{*}{\multicolumn{1}{|c|}{ Skala }} & \multicolumn{2}{c|}{ Statystyki opisowe } \\
\cline { 2 - 3 } & M & SD \\
\hline Spójność rodziny & 19,0 & 10,7 \\
\hline Adaptacyjność rodziny & 18,7 & 9,9 \\
\hline Wzajemne zrozumienie w rodzinie & 16,3 & 6,6 \\
\hline Role rodzinne & 21,5 & 9,8 \\
\hline Trudności rozwojowe & 8,3 & 4,8 \\
\hline Dezintegracja rodzinna & 8,2 & 5,4 \\
\hline Poziom funkcjonalności rodziny & 1,8 & 1,8 \\
\hline
\end{tabular}

Źródło: obliczenia własne

W percepcji dzieci przebywających wspólnie $z$ rodzicami na emigracji w Holandii ich systemy rodzinne charakteryzują się następującymi cechami:

- przeciętnymi wartościami w zakresie spójności,

- niskimi wartościami w obszarze adaptacyjności,

- niskimi wartościami w obszarze wzajemnego zrozumienia,

- przeciętną ilością patologicznych ról rodzinnych,

- nieznacznie zwiększonym wartościami w zakresie trudności rozwojowych,

- nieznacznie zwiększonymi wartościami w zakresie dezintegracji rodziny,

- obniżonymi wartościami na poziomie funkcjonalności systemu rodzinnego.

W celu określenia poziomu nasilenia określonego obszaru funkcjonowania rodziny wyróżniono trzy stopnie: niski, umiarkowany, wysoki. Szczegółowe wyniki badań przedstawiono w tabeli nr 2 . 
Tabela 2. Poziom funkcjonowania rodziny emigracyjnej $\mathrm{w}$ percepcji badanych respondentów

\begin{tabular}{|l|c|c|c|c|}
\hline \multirow{2}{*}{\begin{tabular}{c}
\multirow{2}{*}{$\begin{array}{c}\text { Obszar funkcjono- } \\
\text { wania rodziny }\end{array}$} \\
\cline { 2 - 4 }
\end{tabular}} & niski & $\begin{array}{c}\text { Umiar- } \\
\text { kowany }\end{array}$ & wysoki & \multirow{2}{*}{ OGó£EM } \\
\hline Spójność rodziny & $38,3 \%$ & $44,2 \%$ & $17,5 \%$ & $100 \%$ \\
\hline Adaptacyjność rodziny & $45,8 \%$ & $38,3 \%$ & $15,8 \%$ & $100 \%$ \\
\hline $\begin{array}{l}\text { Wzajemne zrozumienie } \\
\text { w rodzinie }\end{array}$ & $59,2 \%$ & $34,2 \%$ & $6,7 \%$ & $100 \%$ \\
\hline Role rodzinne & $17,5 \%$ & $67,5 \%$ & $15,0 \%$ & $100 \%$ \\
\hline Trudności rozwojowe & $30,8 \%$ & $55,0 \%$ & $14,2 \%$ & $100 \%$ \\
\hline Dezintegracja rodzinna & $20,8 \%$ & $56,7 \%$ & $22,5 \%$ & $100 \%$ \\
\hline Poziom funkcjonalności rodziny & $45,0 \%$ & $49,2 \%$ & $5,8 \%$ & $100 \%$ \\
\hline
\end{tabular}

Źródło: obliczenia własne

Poziom spójności rodziny emigracyjnej ${ }^{20}$. Respondenci wskazali, że ich rodziny charakteryzuje umiarkowany poziom spójności rodzinnej, co klasyfikuje rodziny do systemów odseparowanych, w których więź emocjonalna między członkami pozostaje osłabiona. Granice zewnętrzne, jak i wewnętrzne systemu rodzinnego były częściowo otwarte, przy czym dla członków rodziny jednakowo ważny pozostawał czas wspólnie spędzony oraz czas przebywania w samotności. Decyzje w rodzinie w większości podejmowane były indywidualnie, sporadyczne sytuacje świadczyły o tym, że decyzje zdarzało się podejmować wspólnie. Warto podkreślić, że brak więzi, bliskości, samotność, wzmożona tęsknota za rodziną to głów-

20 Urszula Gruca-Miąsik (w artykule pt. Zastosowanie technik systemowych w diagnozowaniu rodzin i kandydatów na rodziców zastępczych ukazanym w książce pod redakcją M. Deptuły pt. Diagnostyka pedagogiczna i profilaktyka w szkole i środowisku lokalnym, Bydgoszcz 2004) wskazuje, że w ramach poziomu spójności można wymienić kilka typów systemów rodzinnych w zależności od nasilenia wartości: systemy luźne (bardzo niski poziom spójności), systemy odseparowane (niski i umiarkowany poziom spójności), systemy połączone (umiarkowany i wysoki poziom spójności), systemy zwarte (bardzo silny poziom spójności). 
ne bodźce reemigracyjne ${ }^{21}$, które w przypadku osób, które bardzo długo przebywają poza ojczyzną mogą powodować brak równowagi psychicznej czy nawet dysharmonię w podstawowych funkcjach życiowych. Rezultatem takiego stanu zachowania może być nadmierna koncentracja na sprawach materialnych kosztem zaniedbywania kontaktów społecznych, rozwoju osobowego, co jednocześnie osłabia więź emocjonalną w rodzinie ${ }^{22}$.

Poziom adaptacyjności rodziny emigracyjnej. Niespełna połowa badanych respondentów $(45,8 \%)$ oceniła poziom adaptacyjności rodziny jako niski. Rodziny badanych zaliczono do systemów sztywnych ${ }^{23}$, odznaczających się pasywnym, a w niektórych przypadkach agresywnym stylem wyrażania opinii, przy jednoczesnej wyraźnie odznaczającej się autorytarnej kontroli i kierowaniu. Rodziny nie posiadały sprawnych umiejętnościami rozwiązywania problemów, wykazywały się stereotypowym sposobem odgrywania ról rodzinnych, a także sztywnością zasad rodzinnych. W wielu przypadkach zaobserwowano proces zmagania się jednostki ze stresem wynikającym z pobytu na emigracji.

Należy pamiętać, że rodzina znajdująca się w nowej rzeczywistości społecznej na nowo musi zmierzyć się z realiami codziennego życia, zachować własną tożsamość społeczną, ale jednocześnie nauczyć się funkcjonować w innej, „obcej” przestrzeni, w środowisku ludzi posługujących się innym językiem i mających odmienne zainteresowania. Emigracja stanowi poważny czynnik stresogenny, który powoduje postawienie jednostki w obliczu wielu zmian. Zgodnie z perspektywą modelu Lazarusa-Folkma$\mathrm{na}^{24}$ rodzina decydująca się na wspólny pobyt na emigracji nie doświadcza wprawdzie rozłąki doświadczanej w kategoriach osobistych, lecz stoi w obliczu innych wyzwań. Po pierwsze wprowadza do nowego kraju zestaw norm, reguł i ról zakorzenionych w rodzimej kulturze, takich, które

21 M. Galent, Co z tymi Flamakami? Między poczuciem braku stabilizacji a potrzeba relacji intymnych, w: Drogi i rozdroża. Migracje Polaków w Unii Europejskiejpo 1 maja 2004 roku, red. H. Grzymała-Moszczyńska, A. Kwiatkowska, J. Roszak, Kraków 2010, s. 60.

22 P. Boski, Psychologia migracji i akulturacji w społeczeństwie wielokulturowym, w: Drogi i rozdroża. Migracje Polaków w Unii Europejskiej po 1 maja 2004 roku, red. H. Grzymała-Moszczyńska, A. Kwiatkowska, J. Roszak, Kraków 2010, s. 107.

23 W przypadku poziomu adaptacyjności rodzin wyróżnia się systemy: chaotyczny, elastyczny, ustruktualizowany, sztywny. Systemy centralne są bardziej funkcjonalne niż systemy krańcowe.

24 B. Wolańczyk, Imigracja - wyzwanie, zagrożenie, strata. „Niebieska Linia” (2011) nr 6, s. $14-16$. 
się sprawdzały i są jej zasobem. Po drugie osiedlając się w kraju docelowej emigracji, rodzina uczy się nowych reguł życia. Jednak, gdy sprawdzone zasady funkcjonowania się nie sprawdzają, a nowe trudno zaakceptować, wtedy może dochodzić do różnych trudnych sytuacji: np. członkowie rodzin mogą zostać narażeni na osłabienie zdolności do reagowania na stres poprzez zmianę struktury władzy, wymianę ról oraz modyfikację zasad rodzinnych.

Komunikacja - wzajemne zrozumienie w rodzinach emigracyjnych. Pobyt na emigracji dla ponad połowy respondentów $(59,2 \%)$ nie sprzyjał właściwej komunikacji i zrozumieniu. Respondenci wskazywali na wyraźne trudności we właściwym rozumieniu się. W perspektywie procesu badawczego ustalono, że między badanymi dziećmi a ich rodzicami widoczny był znaczny dystans emocjonalny i „sztuczne” bariery w zakresie celów i potrzeb. W rodzinach tych członkowie często odtrącali siebie nawzajem, a dzieci oskarżały rodziców o to, iż muszą funkcjonować w obcym dla nich środowisku.

Badania innych autorów również podkreśliły istnienie pomiędzy członkami rodziny swoistej bariery wynikającej z przekonania (szczególnie powstającego u dzieci), iż pobyt na emigracji nie był związany $\mathrm{z}$ ich dobrowolną decyzjią, lecz podporządkowaniem się planom rodziców ${ }^{25}$. W zakresie komunikacji zaobserwowano również emocjonalną relatywność przejawiającą się w formie lęku, złości, poczucia winy, wynikających $\mathrm{z}$ braku satysfakcjonujących kontaktów między członkami rodziny.

Role rodzinne $w$ rodzinach emigracyjnych. $W$ toku procesu badawczego ustalono, iż w rodzinach przebywających na emigracji w Holandii dominowała umiarkowana ilość ról rodzinnych o charakterze patogennym, charakteryzujących się wzajemnym powiązaniem tożsamości, wysokim nasileniem i komplementarnością.

Trudności rozwojowe w rodzinach emigracyjnych. W percepcji dzieci przebywających z rodzicami na emigracji w Holandii rodzina własna przejawiała umiarkowany stopień bezradności, pesymizmu życiowego czy też stagnacji. Jednak wśród respondentów 14,2\% spostrzegało członków rodziny w kategoriach osób niezaradnych życiowo czy wręcz charaktery-

25 B. Lulek, Samotność dziecka w rodzinie dotkniętej emigracją zarobkowa w kontekście teoretycznym iperspektywie empirycznej, w: Rzeczywistość dziecka, red. J. Krukowiecki, Tarnów 2012, s. 131. 
zujących się pesymizmem. Taki sposób interpretacji zachowań przez respondentów wiązał się ze świadomością, iż większość rodziców wykonuje pracę poniżej własnych kwalifikacji, nie odczuwa zadowolenia z pobytu na emigracji, nie adaptuje się do nowego otoczenia.

Dezintegracja rodzinna w rodzinach emigracyjnych. Ocena stopnia spostrzeganej przez respondentów dezintegracji w rodzinach nie kwalifikowała ich do systemów dysfunkcjonalnych. Pomimo iż występowały określone czynniki mogące powodować tę dezintegrację, m.in. stres związany z utratą kontaktów z dotychczasowym środowiskiem, izolacja członków rodziny przebywających na emigracji (spowodowana samotnością, poczuciem wyobcowania), to jednak większość badanych spostrzegała umiarkowany poziom dezintegracji rodzinnej.

Zdaniem Stanisława Kozaka ${ }^{26}$ przyczyn dezintegracji rodzinnej można szukać również $\mathrm{w}$ fazach procesu emocjonalnego, jaki zachodzi u potencjalnych emigrantów, tj. nadkompensacji oraz dekompensacji. Nadkompensacja wiąże się głównie z koniecznością zabezpieczenia bytu rodzinie, czemu podporządkowana jest cała energia rodziców. Dzieci w tej sytuacji obserwują wyższy poziom postrzegania rodziny jako rodziny zdezorganizowanej. Natomiast dekompensacja (kryzys przystosowania) świadczy o tym, że sposoby radzenia sobie z określonymi sytuacjami, systemy wartości poszczególnych jej członków, które sprawdzały się, nie mają zastosowania w nowej sytuacji.

Poziom poczucia funkcjonalności rodzin emigracyjnych. W badanej próbie dominował umiarkowany poziom poczucia funkcjonalności (49,2\%). Niepokojące są jednak dane dotyczące niskiego poziomu funkcjonalności, które wskazały na $45 \%$ udział respondentów w ocenie. Spostrzeżenia odnoszące się do tego poziomu związane były przede wszystkim z postrzeganiem pobytu na emigracji w kategoriach sytuacji kryzysowej, która negatywnie wpływa na funkcjonowanie całej rodziny.

26 S. Kozak, Patologia eurosieroctwa $w$ Polsce. Skutki migracji zarobkowej dla dzieci i ich rodzin, Warszawa 2010, s. 44. 


\section{Zakończenie}

Specyfika funkcjonowania rodzin przebywających z dziećmi na emigracji jest nieco inna niż w przypadku rodzin doświadczających emigracji wybranych członków rodziny, z których dzieci pozostają w Polsce. W kontekście prowadzonych badań ustalono szereg wniosków dotyczących charakterystyki rodzin emigrujących do Holandii:

- w rodzinach tych obserwuje się osłabioną więź emocjonalną między członkami rodziny, typową dla systemu odseparowanego;

- rodziny zmuszone są do samodzielnego zmagania się z problemami związanymi z procesem adaptacji do nowych warunków życia, a codzienne sytuacje życiowe mogą jawić się jako sytuacje trudne, kryzysowe;

- pojawiają się problemy w zakresie wzajemnego zrozumienia między członkami rodziny, które mogą wpłynąć na jej niski poziom funkcjonowania;

- w rodzinie przebywającej na emigracji występuje umiarkowana ilość patogennych ról rodzinnych;

- w rodzinach emigracyjnych trudności rozwojowe wyrażają się w działaniu schematycznym, stagnacji czy pełnych pesymizmu postawach jej członków, dezintegracja rodzinna osiąga umiarkowany poziom,

- ogólne poczucie funkcjonalności rodziny oceniane jest na poziomie umiarkowanym, choć wyraźnie zaobserwować można również wskazania respondentów odnoszące się do niskiego poczucia funkcjonalności rodziny.

Podsumowując, warto podkreślić, że w przypadku dzieci doświadczających emigracji zarobkowej ważne jest, by rodzice w odpowiedni sposób prowadzili określane działania zaradcze wobec własnych dzieci, m.in. takie jak:

- nawiązywali kontakt z psychologiem w celu określenia sposobów radzenia sobie $\mathrm{z}$ negatywnymi reakcjami dziecka wynikającymi z procesu akulturacyjnego;

- wykorzystali wsparcie pedagogiczne w sytuacji pojawienia się określonych dysfunkcji (zarówno w zachowaniu dziecka, jak i funkcjonowaniu rodziny); 
- wykorzystywali zasoby społeczne i osobowe do rozwiązywania określonych problemów, byli otwarci na szukanie pomocy oraz potrafili korzystać z tej pomocy.

\section{Abstrakt}

Polska rodzina w obliczu emigracji zarobkowej do Holandii. Kwestie adaptacyjne i tożsamościowe

Współczesna emigracja zarobkowa rodzin coraz częściej dotyczy również dzieci. W perspektywie funkcjonowania w nowych warunkach społecznych dziecięca percepcja emigracji zarobkowej może w znaczny sposób odbiegać od percepcji rodzicielskiej. W artykule zaprezentowano badania nad specyfiką funkcjonowania rodzin przebywających na emigracji w Holandii, ukazujące wybrane obszary, takie jak: więź emocjonalna w rodzinie, zdolność do dokonywania zmian, komunikacja, role rodzinne, trudności rozwojowe (schematyzm działania, stagnacja, pesymizm życiowy, bezradność), dezintegracja rodzinna, poczucie funkcjonalności rodziny.

Słowa kluczowe: emigracja zarobkowa, rodzina

\section{Abstract}

Polish family in the face of economic emigration to the Netherlands. The issues adaptive and identity

Contemporary economic emigration of families also increasingly affects children. In the perspective of functioning in new social conditions, the child's perception of economic emigration may significantly differ from parental perception. The article presents research on the specifics of the functioning of families living in exile in the Netherlands, showing selected areas such as: emotional bond in the family, ability to make changes, communication, family roles, developmental difficulties (operational stru- 
cture, stagnation, life pessimism, helplessness), disintegration family, family functionality.

Keywords: economic emigration, family

\section{Bibliografia}

Cieślińska B., Emigracje bliskie i dalekie Studium współczesnych emigracji zarobkowych na przykładzie województwa podlaskiego, Białystok 2012.

Kolankiewicz M., Dziecko w sytuacji rozłąki z rodzicami, „Pedagogika Społeczna" (2008) nr 3 (29), s. 81-86.

Biernat T., Krakowiak P., Leszniewski T., Emigracja zarobkowa jako sytuacja trudna ( $w$ świetle aktualnych badań nad polskimi migrantami $w$ Wielkiej Brytanii), „Pedagogika Społeczna (2019) nr 1 (71), s. 181-199.

Boski P., Psychologia migracji i akulturacji w społeczeństwie wielokulturowym, w: Drogi i rozdroża. Migracje Polaków w Unii Europejskiejpo 1 maja 2004 roku, red. H. Grzymała-Moszczyńska, A. Kwiatkowska, J. Roszak, Kraków 2010, s. 107-132.

Danielewicz W., Rodzina ponad granicami. Transnarodowe doświadczenia wspólnoty rodzinnej, Białystok 2010.

Galasiński D., Galasińska A., Lost in Communism, Lost in Migration: Narratives of the Post-1989 Polish Migrant Experience, „Journal of Multicultural Discourses" (2007), no. 1, s. 47-62.

Galent M., Co z tymi Flamakami? Między poczuciem braku stabilizacji a potrzebą relacji intymnych, w: Drogi i rozdroża. Migracje Polaków w Unii Europejskiej po 1 maja 2004 roku, red. H. Grzymała-Moszczyńska, A. Kwiatkowska, J. Roszak, Kraków 2010, s. 239-252.

Gaś Z., Badanie zapotrzebowania na profilaktykęw szkole. Poradnik dla szkolnych liderów profilaktyki, Lublin 2004.

Gizicka D., Gorbaniuk J., Szyszka M., Rodzina w sytuacji rozłakimigracyjnej, Lublin 2010.

Gruca-Miąsik U., Zastosowanie technik systemowych w diagnozowaniu rodzin i kandydatów na rodziców zastępczych, w: Diagnostyka pedagogiczna i profilaktyka w szkole iśrodowisku lokalnym, red. M. Deptuła, Bydgoszcz 2004, s. 27-45. 
Jacyniak A., Płużek Z., Świat ludzkich kryzysów, Kraków 1996.

Kozak S., Patologia eurosieroctwa w Polsce. Skutki migracji zarobkowej dla dzieci i ich rodzin, Warszawa 2010.

Leska-Ślęzak J., Ślęzak J., Młoda polska emigracja do Holandii, „Cywilizacja i Polityka" (2016) nr 14, s. 174-182, s. 208-221.

Leska-Ślęzak J., Sytuacja mniejszości narodowych i etnicznych w Holandii, w: Mniejszości narodowe i etniczne w Polsce i Europie. Aspekty polityczne i społeczne, red. A. Sakson, Toruń 2014.

Lulek B., Samotność dziecka $w$ rodzinie dotkniętej emigracja zarobkowa $w$ kontekście teoretycznym i perspektywie empirycznej, w: Rzeczywistość $d z i e c k a$, red. J. Krukowiecki, Tarnów 2012.

Matsumoto D., Yuang L., Psychologia międzykulturowa, Gdańsk 2007.

Mead M., Kultura i tożsamość. Studium dystansu międzypokoleniowego, Warszawa 2000.

Oberg K., Culture Shock. Adjustment to New Cultural Environments, „Practical Anthropology" (1960) no. 7 (pobrano dnia 26.03.2014 z http://agemethnomedizin.de/download/cu29_2-3_2006_S_142-146_Repr_Oberg. pdf).

Olszewska D., Migracje Polaków po przystąpieniu do Unii Europejskiej. Szansa dla polskich obywateli czy zagrożenie gospodarcze dla Polski?, w: Polska $w$ Unii Europejskiej, red. J. Fischer, Warszawa 2009.

Ryan L., Sales R., Family Migration: The Role of Children and Education in Family Decision-Making Strategies of Polish Migrants in London, „International Migration” 2 (2013), s. 90-103, https://doi.org/10.1111/j.14682435.2010.00652.x.

Szczygielska I., Migracje zarobkowe kobiet i ich wptyw na funkcjonowanie rodzin, Warszawa 2013.

Toruńczyk-Ruiz S., Being together or apart? Social networks and notions of belonging among recent Polish migrants in the Netherlands, „CMR Working Papers" (2008) nr 40/98.

White A., Polish Families and Migration Since EU Accession, Bristol 2017.

Wolańczyk B., Imigracja - wyzwanie, zagrożenie, strata. „Niebieska Linia” (2011) nr 6, s. 14-16. 